\title{
GROUP COUNSELING WITH SELF- MANAGEMENT TECHNIQUES: EFFECTIVE STRATEGIES FOR REDUCING NOMOPHOBIA AMONG ADOLESCENTS
}

\author{
Dian Ari Widyastuti*, Siti Muyana, \\ *Correspondent Author
}

Dian Ari Widyastuti

Universitas Ahmad Dahlan

Jalan Ringroad Selatan, Kragilan,

Tamanan, Banguntapan, Bantul, Daerah Istimewa Yogyakarta

Indonesia

Email: dian.widyastuti@bk.uad.ac.id

Siti Muyana

Universitas Ahmad Dahlan

Jalan Ringroad Selatan, Kragilan,

Tamanan, Banguntapan, Bantul, Daerah

Istimewa Yogyakarta

Indonesia

Email: dian.widyastuti@bk.uad.ac.id

Halaman

58-63

\section{ABSTRAK}

This study aimed to find out the effectiveness of group counseling with self-management technique in reducing nomophobia among adolescents. This experimental research applied one group pretest-posttest design. The participants in this study were eight Vocational High School students in Yogyakarta City, Indonesia, who were recruited using simple random sampling technique. The data of the study were collected using Nomophobia scale and analyzed using Wilcoxon test. Based on the result of data analysis, it could be concluded that group counseling with self-management techniques was effective in reducing nomophobia among adolescents, especially Vocational High School students in Yogyakarta, Indonesia. School counselors could use the result of this study as a reference to help students reduce nomophobia through group counseling with self-management techniques.

Keyword: nomophobia, self-management, group counseling

\begin{abstract}
INTRODUCTION
Almost every person, especially teenagers, has a smartphone since it has become an important part of adolescent life (Pavithra MB, 2015; Lemola, et al., 2015; Chung, et al., 2018; Schweizer, et al., 2017). It allows individuals to conveniently establish communication through social networks such as Facebook, Twitter, WhatsApp, and Line. In addition to social network, they may easily find entertainment Youtube, TikTok, and games on. They may also access information through applications such as Google and various online news applications. Despite the benefits a smartphone offers, it can trigger
\end{abstract}

adolescents' anxiety when they are away from the smartphone.

The anxiety experienced by teenagers when they are away from a smartphone is called nomophobia. The word "nomophobia" comes from English word, standing for "No Mobile Phone Phobia", a phobia without a mobile phone (King, et al., 2014). Nomophobia has infected people around the world, including in Indonesia. It can even be considered as a disease among today's adolescents (Muyana \& Widyastuti, 2017). As evidence, the results of a study conducted by Widyastuti and Muyana (2018) on 540 Vocational High School students in 


\section{9| PSIKOPEDAGOGIA}

JURNAL BIMBINGAN DAN KONSELING

Vol.8, No.2, December 2019

Yogyakarta, Indonesia, who were recruited through a simple random sampling technique, showed that $5 \%$ of their participants' nomophobia was categorized as very high (\%), $31 \%$ of them was categorized as high, $35 \%$ of them was categorized as medium, $24 \%$ of them was categorized as low, and $5 \%$ of them was categorized very low. Based on the results of this study, it is necessary to treat adolescents with nomophobia to support their developmental tasks.

One of the efforts can be made to overcome the issue of nomophobia among adolescents is by implementing group counseling with self-management techniques. As Widyastuti \& Muyana (2019) argue, group counseling with selfmanagement techniques is seen as one of the appropriate solutions for dealing with nomophobia among adolescents. Applying group counseling with self-management techniques, adolescents are expected to direct and get rid of their anxiety when they are away from their smartphones, allowing them to be more independent and productive.

This study aimed to examine the effectiveness of group counseling with selfmanagement techniques in reduce nomophobia among adolescents. Nomophobia is a unique psychological disorder, which develops in a today's modern society. The results of the study are expected to be used as a reference for school counselors to help students reduce nomophobia.

\section{METHODOLOGY}

This experimental research applied one group pretest-posttest design. The participants were eight Vocational High School students in Yogyakarta City, Indonesia, who were recruited using simple random sampling. The data were collected using the nomophobia scale and analyzed using Wilcoxon test.

\section{RESULTS AND DISCUSSION}

Before the treatment, i.e., group counseling with self-management techniques, was given, participants' nomophobia level was measured using the nomophobia scale (pretest). Table 1 shows that all participants' nomophobia was categorized as very high.

Table 1

Description of Nomophobia in Subjects Before Treatment

\begin{tabular}{cccl}
\hline No. & Subject & Pretest & Category \\
\hline 1. & ES & 86 & Very High \\
2. & SB & 92 & Very High \\
3. & MH & 86 & Very High \\
4. & TF & 90 & Very High \\
5. & NK & 83 & Very High \\
6. & FL & 84 & Very High \\
7. & TR & 88 & Very High \\
8. & PH & 83 & Very High \\
\hline
\end{tabular}

Following the pretest, the treatment was given. It was done for several meetings until a change in participants' anxiety was noticed. After the treatment was given, the participants' nomophobia was measured using nomophobia scale again (posttest). Table 2 displays the change in participants' nomophobia after receiving treatment. Data from the pretest and posttest results were further analyzed using the Wilcoxon test to find out the effectiveness of the treatment. The Wilcoxon analysis result is presented in Table 3.

Table 2

\begin{tabular}{cccc}
\multicolumn{4}{c}{ Participants' } \\
\hline No. & Subject & Posttest & Category \\
\hline 1. & ES & 52 & Low \\
2. & SB & 44 & Low \\
3. & MH & 45 & Low \\
4. & TF & 39 & Very Low \\
5. & NK & 51 & Low \\
6. & FL & 65 & Medium \\
7. & TR & 61 & Medium \\
8. & PH & 55 & Low \\
\hline
\end{tabular}

Table 3

Wilcoxon Analysis Results

Test Statistics ${ }^{b}$

Posttest - Pretest

$$
\text { Z }
$$$$
-2.521^{a}
$$

Asymp. Sig. (2-tailed) .012

By comparing the pretest and posttest scores, supported by the results of the 
Wilcoxon analysis at the significance level $<0.05$, it could be concluded that the group counseling of self-management technique was effective for reducing nomophobia among adolescents.

Vocational High School students, as millenials, could quickly adapt to today's technologies, including using smartphones. This phenomenon may influence their habits and lifestyle. As Mulyana, et al. (2018) state, smartphones play central roles in adolescents' life due to its entertainment, communication, and information features. Unrestricted use of smartphone can adversely affect adolescents, as they become more focused on the device instead of establishing interaction with their environment.

Smartphone mobility, which benefits and helps teenagers, can also cause serious problems (Yildirim, 2014; Yildirim \& Correia, 2015; Argumosa-Villar, et al., 2017; Kalaskar, 2015). The relationship between adolescents and smartphones affects their interpersonal behavior and social habits (King, et al., 2013; Gezgin, et al., 2018). At their age, adolescents' developmental task is to establish close relationships with other people or peers. When they are too enganged with smartphones than with their surrounding environment, their future social life may be affected. When adolescents' social skills is not well-trained, they are at risk of failure in living a social life.

Since smartphone has become inseparable part of adolescents' daily life, its high intensity of usage may affect their learning focus. It can also triggers anxiety when they are separated from their smartphone, a condition known as nomophobia. It is a term that refers to a group of behaviors caused by anxiety related to mobile phone usage. A group of psychiatric researchers in Brazil has defined a new disorder called nomophobia or an acronym for no-mobile phone phobia, which describes an individual's anxiety when away from a mobile phone device or what is currently developing known as a smartphone (Cheever, et al., 2014). King, et al. (2013) consider nomophobia as a modern personality disorder to describe the discomfort or anxiety caused by the desire to be close to virtual communication devices. Thus, it can be concluded that nomophobia is a phobia experienced by individuals when they are away from their smartphones.

Nomophobia in adolescents is a serious problem because if it is not immediately addressed, adolescents' future life aspects may be affected. Vocational High School is one of the levels of formal institutions in the education dimension which has a strategic role in educating, improving, and internalizing values in students. At this level of education, school counselors can provide special services with curative functions to help students solve and overcome their nomophobia.

One of the school counselor' services is group counseling with self-management technique. It proven to be effective in reducing nomophobia among adolescents because of its group approach. A group approach is considered effective because it provides opportunities for individuals to socialize with their surroundings (Stephens, et al., 2010; Bulantika, et al., 2018; Pérusse, et al., 2009; Rose \& Steen , 2014).

In addition to group approach, the treatment in this study also applied selfmanagement techniques to reduce nomophobia among adolescents. It is a technique for managing individual behavior in order to achieve independence and productivity (Briesch DuBois, et al., 2017; Grady, et al., 2014). In practice, the responsibility for the success of selfmanagement-based group counseling rests with the client (i.e., student). In group counselling with self-management technique, the counselor acts as an idea originator, a facilitator who helps design programs, and a motivator for the client (McMahon, 2009; Landon \& Schultz, 2018; Powel, et al., 2010).

This counseling is done through several stages, namely self-monitoring (recording the presence or absence of a person's behavior), self-evaluation (assessing the quality of a person's behavior using a rating 


\section{1| PSIKOPEDAGOGIA}

JURNAL BIMBINGAN DAN KONSELING

Vol.8, No.2, December 2019

scale), and self-reinforcement (after determining a behavior quality so they can choose the reward) (King-Sears, 2006). Through these stages, students are expected to obtain new learning experiences to overcome their nomophobia.

Through group counseling with selfmanagement techniques, individuals are expected to perform self-management to fulfill their needs and achieve their goals. In broader sense, It is expected that students can controlg their overall existence (i.e., physical, emotional, mental, soul existence) and life realities. The main strategy in selfmanagement is that individuals try to understand themselves with all their weakness and strengths. Individuals with proper time management will never lose time and opportunity to complete their tasks. Such individuals are able to make decisions quickly and have initiative and bright ideas related to their tasks.

Adolescents with good self-management are able to determine priority goals by using time effectively and efficiently. They can make changes to achieve a prosperous life. That is, for adolescents with nomophobia, the final goal of group counseling with selfmanagement technique is to deliver a new individual with good self-management skill to use smartphone based on their needs, so that they complete other tasks as a student. In other words, adolescents can achieve developmental tasks according to their age and can achieve a prosperous life.

The results of this study support other studies that found the effectiveness of group counseling with self-management techniques in solving other problems. The results of these studies, among others, show the effectiveness of group counseling with self-management techniques to reduce aggressiveness in adolescents (Sa'diyah, et al., 2017), reduce learning anxiety in students (Hermanto, 2017), reduce Facebook addiction (Triantoro, 2013), even Group counseling self-management techniques are also effectively used in the medical field such as in patients with heart failure (Powell, et al., 2010), the application of self-management in patients with chronic health (Lawn \& Schoo, 2010). Selfmanagement is one of the effective strategies to solve various problems, especially nomophobia among adolescents.

\section{CONCLUSION}

Based on the result of the study, it can be concluded that group counseling with selfmanagement techniques is effective in reducing nomophobia among adolescents. School counselors can use this finding as a reference to help students reduce nomophobia through group counseling with self-management techniques.

\section{REFERENCE}

Argumosa-Villar, L., Boada-Grau, J., \& VigilColet, A. (2017). Exploratory investigation of theoretical predictors of nomophobia using the Mobile Phone Involvement Questionnaire (MPIQ). Journal of adolescence, 56, 127-135.

Briesch DuBois, J. M., Briesch, A. M., Hoffman, J. A., Struzziero, J., \& Toback, R. (2017). Implementing self-management within a group counseling context: Effects on academic enabling behaviors. Psychology in the Schools, 54(8), 852-867.

Bulantika, S. Z., Wibowo, M. E., \& Jafar, M. (2018). Group counseling with systematic desensitization techniques and thought-stopping techniques to reduce social anxiety. Jurnal Bimbingan Konseling, 7(2), 106-112.

Cheever, N., Rosen, Larry., et al. 2014. Out of sight is not out of mind: The impact of restricting wireless mobile device use on anxiety levels among low, moderate and high users. Computers in Human Be havior, 37:290-297.

Chung, J. E., Choi, S. A., Kim, K. T., Yee, J., Kim, J. H., Seong, J. W., ... \& Gwak, H. S. (2018). Smartphone addiction risk and daytime sleepiness in Korean adolescents. Journal of paediatrics and child health, 54(7), 800-806.

Gezgin, D. M., Hamutoglu, N. B., SezenGultekin, G., \& Ayas, T. (2018). The Relationship between Nomophobia and Loneliness among Turkish 
Adolescents. International Journal of Research in Education and Science, 4(2), 358-374.

Grady, K. L., De Leon, C. F. M., Kozak, A. T., Cursio, J. F., Richardson, D., Avery, E., ... \& Powell, L. H. (2014). Does self-management counseling in patients with heart failure improve quality of life? Findings from the Heart Failure Adherence and Retention Trial (HART). Quality of life research, 23(1), 31-38.

Hermanto, R. J. (2017). Pengaruh penggunaan strategi selfmanagement dalam konseling kelompok terhadap kecemasan belajar siswa kelas VIII SMP Jalan Jawa. HELPER: Jurnal Bimbingan dan Konseling, 33(1).

Kalaskar, P.B. (2015). A study of awareness of development of Nomophobia condition in Smart Phone user Management Students in Pune city. ASM's International E-Journal on Ongoing Research in Management and $I T, 10: 320-326$.

King, A. L. S., Valenca, A. M., Silva, A. C. O., Baczynski, T., Carvalho, M. R., \& Nardi, A. E. (2013). Nomophobia: Dependency on virtual environments or social phobia?. Computers in Human Behavior, 29(1), 140-144.

King, A. L. S., Valença, A. M., Silva, A. C., Sancassiani, F., Machado, S., \& Nardi, A. E. (2014). "Nomophobia": Impact of cell phone use interfering with symptoms and emotions of individuals with panic disorder compared with a control group. Clinical practice and epidemiology in mental health: $C P$ \& $E M H, 10,28$.

King-Sears, M.E. (2006). Self-management for students with disabilities: the importance of teacher follow-up. International Journal of Special Education, 21(2):94-108.

Landon, T. J., \& Schultz, J. C. (2018). Exploring rehabilitation counseling supervisors' role in promoting counselor development of ethical fluency. Rehabilitation Counseling Bulletin, 62(1), 18-29.
Lawn, S., \& Schoo, A. (2010). Supporting self-management of chronic health conditions: common approaches. Patient education and counseling, 80(2), 205-211.

Lemola, S., Perkinson-Gloor, N., Brand, S., Dewald-Kaufmann, J. F., \& Grob, A. (2015). Adolescents' electronic media use at night, sleep disturbance, and depressive symptoms in the smartphone age. Journal of youth and adolescence, 44(2), 405-418.

McMahon, H. G., Mason, E. C. M., \& Paisley, P. O. (2009). School counselor educators as educational leaders promoting systemic change. Professional School Counseling, 13(2).

Mulyana, M., Mulyana, A. R., \& Dewi, A. K. (2018). Perancangan Kampanye untuk Menumbuhkan Kesadaran Generasi Millenial terhadap Dampak Nomophobia. Jurnal Rekamakna Institut Teknologi Nasional, 1-10.

Muyana, S., \& Widyastuti, D. A. (2017, August). Nomophobia (No-Mobile Phone Phobia) Penyakit Remaja Masa Kini. In Seminar Nasional Bimbingan Konseling Universitas Ahmad Dahlan (Vol. 2).

Pavithra MB, et al. 2015. A Study On Nomophobia - Mobile Phone Dependence, Among Students Of A Medical College In Bangalore. National Journal of Community Medicine. 6(2): 340-344.

Pérusse, R., Goodnough, G. E., \& Lee, V. V. (2009). Group counseling in the schools. Psychology in the Schools, 46(3), 225-231.

Powell, L. H., Calvin, J. E., Richardson, D., Janssen, I., De Leon, C. F. M., Flynn, K. J., ... \& HART Investigators. (2010). Self-management counseling in patients with heart failure: the heart failure adherence and retention randomized behavioral trial. Jama, 304(12), 1331-1338.

Rose, J., \& Steen, S. (2014). The achieving success everyday group counseling model: Fostering resiliency in middle school students. Professional School Counseling, 18(1). 


\section{3| PSIKOPEDAGOGIA}

JURNAL BIMBINGAN DAN KONSELING

Vol.8, No.2, December 2019

Sa'diyah, H., Chotim, M., \& Triningtyas, D. A. (2017). Penerapan teknik self management untuk mereduksi agresifitas remaja. Counsellia: Jurnal Bimbingan dan Konseling, 6(2), 6778.

Schweizer, A., Berchtold, A., Barrense-Dias, Y., Akre, C., \& Suris, J. C. (2017). Adolescents with a smartphone sleep less than their peers. European journal of pediatrics, 176(1), 131-136.

Stephens, D., Jain, S., \& Kim, K. (2010). Group counseling: Techniques for teaching social skills to students with special needs. Education, 130(3).

Triantoro, B. (2013). Penerapan konseling kelompok behavioral dengan teknik self management untuk mengurangi kecanduan facebook pada siswa kelas VIII-C SMP Negeri 2 Nganjuk. Jurnal BK Unesa, 4(1).

Widyastuti, D. A., \& Muyana, S. (2018). Potret Nomophobia (No Mobile Phone Phobia) di Kalangan Remaja. Jurnal Fokus Konseling, 4(1), 62-71.

Widyastuti, D. A., \& Muyana, S. (2019, June). The influence of selfmanagement in using gadgets against nomophobia in adolescents. In International Conference on Social Science and Character Educations (ICOSSCE 2018) and International Conference on Social Studies, Moral, and Character Education (ICSMC 2018) (pp. 53-56). Atlantis Press.

Yildirim, C. (2014). Exploring the dimensions of nomophobia: Developing and validating a questionnaire using mixed methods research.

Yildirim, C., \& Correia, A. P. (2015). Exploring the dimensions of nomophobia: Development and validation of a self-reported questionnaire. Computers in Human Behavior, 49, 130-137. 